\title{
Testing the sustainability of the Croatian military forces: A system dynamics approach
}

\author{
Emil Tustanovski ${ }^{1, *}$, Mirjana Pejić Bach ${ }^{1}$ and Ilko Vrankić ${ }^{1}$ \\ ${ }^{1}$ Faculty of Economics and Business, University of Zagreb \\ Trg J. F.Kennedyja 6, 10000 Zagreb, Croatia \\ E-mail: 〈\{emil.tustanovski@gmail.com,mpejic@efzg.hr,ivrankic@efzg.hr\}〉
}

\begin{abstract}
In line with global trends, the Croatian military is currently going through a transformation, but is being stifled by a long recession and negative demographic trends. The purpose of this article is to outline the possibilities of applying system dynamics models in testing the sustainability of the Croatian military forces (CMF) with respect to their size and composition. The article mainly focuses on the demographic trends and their implications on the CMF. After a brief exposition of the research done in this field to date, the article presents two developed models - a demographic model and a military recruitment model. The models were carefully tested using validation tests suitable for system dynamics modelling. Subsequent to validation, the models were merged into a single integral system dynamics model of the CMF. Three experiments were conducted based on different fertility values, and the impact of demographic trends, which emerge from the different fertility levels. The results of the simulation, based on demographic data from the 2011 Census, as well as estimated data, though not accessible at the time, suggest that the Croatian military will encounter difficulties in meeting its demands for recruits in the next 20-30 years. Further implications of current demographic trends on the CMF's sustainability are discussed towards the end of the paper. Since basic inputs for any organization are labor and capital, the problem is addressed from two complementary perspectives: a demographic and a financial perspective.
\end{abstract}

Key words: system dynamics, military forces, demography, fertility

Received: October 3, 2014; accepted: December 30, 2014; available online: March 30, 2015

DOI: 10.17535 /crorr.2015.0005

\section{Introduction}

During the last thirty years, four major events have changed the perception of what constitutes a modern army. The breakdown of the Soviet Union marked the end of the Cold War, shifting focus from maintaining a large military force for deterrence purposes to that of a two-theatre approach to warfare [23]. The

${ }^{*}$ Corresponding author 
events of 9/11 and subsequent wars in Afghanistan and Iraq have brought attention to the need for asymmetric and urban warfare abilities, in addition to highlighting international terrorism as a growing threat to global security. Rapid technological advancement in electronics and communication has opened up new possibilities and challenges for defense doctrines with the introduction of robotics and 'intelligent' weaponry to the battlefield. Furthermore, the global economic crisis of 2007 introduced sterner budgetary constraints and brought the cost-effectiveness of military programs back into public focus [24].

To adapt to the needs of modern warfare, some of the world's military organizations are undergoing modernization and significant restructuring. Since military organizations are often large and complex systems, such changes pose a challenge for most countries because of the significant effect the military has at a social and economic level due to the size of its budget, workforce and other consequences that stem from these choices.

The primary application for system dynamics models is to facilitate support for decision-making in regards to complex environments. Due to the nature of both the organizational and logistical aspects of the military, as well as warfare itself, there is a continued interest in the military application of such models, since such support could bring a decisive edge in military situations. A major contributor to the field is R.G. Coyle, who first explored the potential of system dynamics for providing an overall view of problems and the dynamics of military operations, published in his model of a hypothetical World War III [4]. From that time onwards, system dynamics have been applied to most aspects of defense and military related issues. A significant amount of research has been done in the field of supply management simulations, whether it was modelling military equipment support [5], weapon maintenance or supply systems [10].

System dynamics have been successfully applied in other related areas as well. In strategic project management, system dynamics models have demonstrated the ability to improve significantly the quality and performance of management on complex projects [15]. In combination with discrete event simulations, system dynamics have been successfully utilized in developing frameworks for modelling combat situations with the use of Lanchester Laws [2]. They have also been used to test whether some of the same factors influence both violent conflicts and sustainable development [28], as well as creating a model to evaluate counter-insurgency policies [1]. Manpower planning models have been used to see how recruitment and attrition affects the costs of organizations with different hierarchies [11], and training force sustainment models have been successful in illustrating the possibility of creating a bullwhip effect even in situations related to human resource management [27].

Although system dynamics research has been ongoing in Croatia for the last couple of decades, a very small part of it is applied to military issues. Research into the demographic sustainability of the Croatian military was being 
carried out, and a system dynamics model created based on the military's previous organizational structure [26], but due to the abandonment of conscription in favor of creating a smaller, professional military force in 2008, it is no longer applicable to the current situation.

Consequently, the decision was made to create a new manpower planning model of the Croatian Armed Forces with emphasis on demographic sustainability to determine whether the new organization has the potential for long-term sustainability and to highlight the issues that could arise due to the specific circumstances in the country and of the model. The purpose of this paper is to determine the possibilities of using system dynamics as a tool for evaluating the sustainability of a predetermined combination of manpower, equipment, training and other aspects that constitute a military force. The main thesis of this paper is that system dynamics can be used as a tool to provide an overview of these effects and to determine the viability and long-term sustainability of planned organizational transitions.

The paper consists of five parts. Following a brief introduction and literary overview, the structure and the dynamics of the models are presented in the second part. The third part explains the design of the experiment, and presents its results. The implications of the results are discussed in the fourth part, and a conclusion is offered in the fifth and final part.

\section{Understanding the dynamics of sustainability of Croatian Military Forces}

There are several approaches for determining the sustainability of complex organizations such as the military. The criteria for differentiation are the definition of sustainability and the benchmarks used in the research, as well as factors used to determine whether the observed organization is sustainable. In this case, we directed our efforts into modelling and observing whether a change in dominant demographic trends (i.e. low fertility) affect the ability of the Croatian military to fill its ranks appropriately, based on current laws and procedures that govern the recruitment process. The data on the demographic trends obtained through experimentation with the model will also be used in the discussion to suggest other mechanisms that can affect the long-term sustainability of Croatian military forces.

In order to achieve this, two models were created: a demographic model and a recruitment model. Both models were developed using the "step-by-step" approach [22], and tested using the dimensional consistency test, the extreme conditions test and the behavior sensibility test. Although the results of the validation tests are not shown in this article for reasons of brevity, they were conducted during the building process to assure consistency of the results, as well as reliability of the model. 


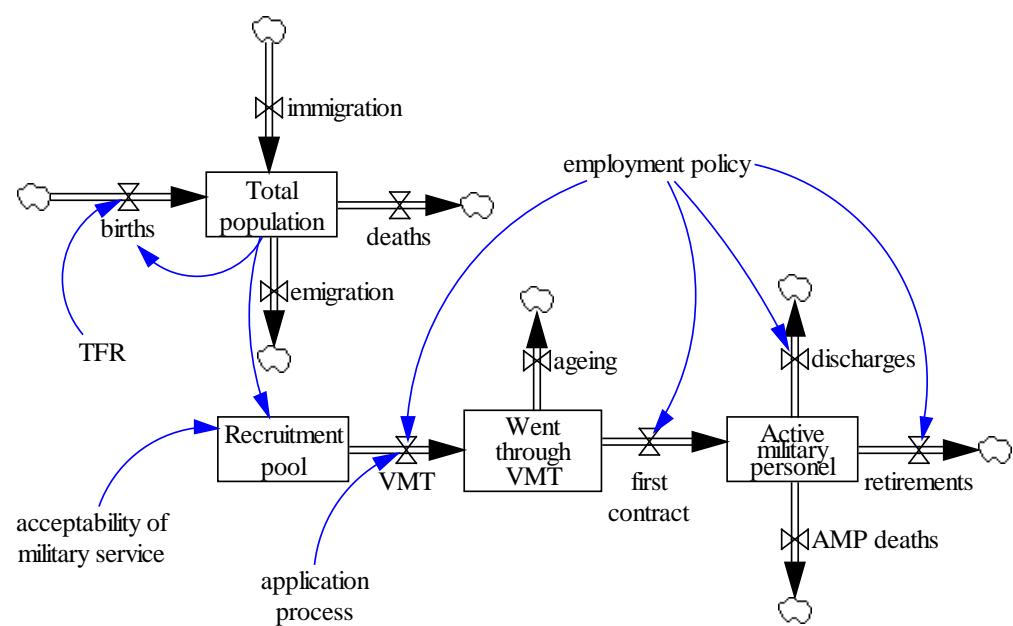

Figure 1: The simplified structural diagram showing the main flow, including critical elements of the model.

The structural diagram in Figure 1 is a necessary simplification owing to the fact that the full model consists of 178 elements and as many equations, and as such exceeds the size limitations of this format. The full model, the equations and the micro-data used in the simulations are available on demand.

\subsection{The demographic model}

The demographic model was designed as a cohort-component model divided into three branches: the male branch, the female branch and the immigration branch. Each branch is divided further into age-based cohorts, chosen to enable observation of the three variables derived from different combinations of the said cohorts: the number of female citizens in fertile age, the number of citizens that are (based on age criteria) eligible to apply for military service, as well as the size of the workforce. Each cohort has a single inflow (births or maturation) and three outflows (maturation, emigration and dying) which are determined mostly by external factors, such as fertility and mortality rates, as well as the estimated rate of emigration for each cohort. The only exceptions are the "Female RA and older" and "Male RA and older" variables, where the maturation outflow is not required.

The use of low-resolution cohort-component analysis and actual population data for Croatia in the model, as well as the need to preserve the age structure of the population throughout the duration of the simulation, required certain modifications to the otherwise straightforward maturation or ageing mechanism in the form of additional lookups and delays. 
However, due to legal limitations of applying for citizenship [17] and/or military service [19], its annual rate, as well as other practical limitations, there was no need to preserve such details in the age and gender structure of immigrants. Therefore, immigration is represented by a simple population model. Nevertheless, the number of female immigrants does affect the rate of births in the other branches, and its estimated proportion is included in "the number of women of childbearing age" variable. The number of births is based on the number of women of childbearing age and the total fertility rate (TFR), which forms the basis for our experiments.

\subsection{The recruitment model}

The models are connected through the "recruitment pool" variable, which estimates the number of people eligible for military service, and assumes that male and female members of the population have an equal interest in serving which currently is not empirically correct, but it can be considered as best-case scenario. Since military service is voluntary in Croatia, the constant "ACCEPTABILITY OF MILITARY SERVICE" has been added to account for the proportion of people from the age group that would consider joining. The variable "application process" in the structural diagram serves as a proxy for a group of variables that determine the number of people sent to Voluntary Military Training (VMT) each year. These variables include "SHARE READY TO APPLY LOOKUP", "PLANNED TESTING LOOKUP", the "Applied", "On hold", "On hold T", and "Tested" stock variables, in addition to "testing", "later testing", and "gave up" outflows.

A person going through VMT can either quit during training, graduate or graduate as a military specialist. People that quit, exit the system completely; people that graduate to become military specialists are employed for their special skills, and are sent to their respective posts immediately after successfully completing VMT, while others are sent to the "went through VMT" stock variable. From that point on, they can exit the system due to ageing, or upon gaining employment in the military.

According to Croatian law [20], a commissioned soldier can sign a contract with the military three times: the first contract lasts for three years, the second for five years, and the third one for six years. After signing the second contract, a soldier with an exemplary record and an adequate level of education may be considered for advancement to the position of a non-commissioned officer. The same criteria apply for advancement into the rank of a commissioned officer, except that the candidate chosen to the position of commissioned officer has to go through one year of additional training. The military's internal structure, and the flow between ranks, is represented by the "active military personnel" proxy variable in the structural diagram. 
There are several reasons as to why the values of outflows from the stock variables 3 years, 5 years, 6 years, NCO's, Commissioned officers, and Military specialists are determined by values stored in lookups, and not by the feedback loops in the model itself. The first one is that not enough data about the composition of the Croatian military forces is publicly available to develop reliably what in a sense would be an autonomous military restructuring model. The second reason is that the decisions on the number of soldiers to be recruited, discharged or retired can be made by the Croatian Parliament, based on a suggestion from the Croatian Government as necessary [19], and as such are subject to a number of discrete political, military and economic circumstances. All the Croatian Government's decisions concerning military personnel management are represented by the "employment policy" proxy variable, which determines the number of soldiers to be tested, employed, discharged or retired.

The model also calculates several key indicators that do not have an essential role in the functioning of the model, and illustrates some side issues that provide a valuable context for the results. The equations for these indicators are given below:

$$
\mathrm{L}=\mathrm{P}_{\mathrm{t}}-\mathrm{P}_{\mathrm{F} 0-14}-\mathrm{P}_{\mathrm{F} 15-17}-\mathrm{P}_{\mathrm{FRA}+}-\mathrm{P}_{\mathrm{M} 0-17}-\mathrm{P}_{\mathrm{MRA}+}
$$

The workforce $(\mathrm{L})$ variable includes all population members of working age (between 18 and the retirement age), and calculated by subtracting the populations of age groups "Female age 0 to 14 " $\left(\mathrm{P}_{\mathrm{F} 0-14}\right)$, "Female age 15 to 17 " $\left(\mathrm{P}_{\mathrm{F} 0-14}\right)$, "Female RA and older" $\left(\mathrm{P}_{\mathrm{FRA}+}\right)$, "Male age 0 to 17 " $\left(\mathrm{P}_{\mathrm{M} 0-17}\right)$ and "Male RA and older" ( $\left.\mathrm{P}_{\mathrm{MRA}+}\right)$ from the total population $\left(\mathrm{P}_{\mathrm{t}}\right)$.

$$
\mathrm{l}_{\mathrm{Pt}}=\frac{\mathrm{L}}{\mathrm{P}_{\mathrm{t}}}
$$

The share of the workforce in the total population $\left(l_{\mathrm{Pt}}\right)$ indicates the share of the total population that is of working age.

$$
\mathrm{R}_{\mathrm{T}}=\mathrm{R}_{\mathrm{C}}+\mathrm{R}_{\mathrm{M}}
$$

The number of total reserves $\left(\mathrm{R}_{\mathrm{T}}\right)$ comprises the number of contractual reserves $\left(R_{C}\right)$ and the number of mobilizational reserves. It is the number of troops that can be mustered at any time in case of an armed conflict, and depends on the demographic structure of the population, including the number of people that have undergone military training. 


\section{Simulation results analysis}

\subsection{Experiment design}

The main focus of this paper is the demographic trends in Croatia over the next 50 years and their impact on the Croatian Armed Forces, especially in regard to changes in the total fertility rate, which is widely recognized as a key aspect of Croatia's declining population over the last several decades. The experiment was designed to determine whether proposed demographic trends would be able to sustain the needs of the military manpower under certain conditions and to find the variables exerting the greatest influence on such outcomes.

To that effect, three scenarios were chosen to monitor changes in the size and structure of Croatia's total population during the observed period: lowfertility Scenario 1, medium fertility Scenario 2, and high fertility Scenario 3. These scenarios were devised by Gelo, Akrap and Čipin [12], and the fertility values are presented in Table 1.

The initial values for the stock variables representing different age groups of both the male and female population were sourced from the results of the 2011 Census [8], and the mortality rates for these groups were calculated as weighted averages of the mortality rates for the appropriate ages as published in the 2012 Statistical Yearbook [7]. The maturation rates, found in the lookups of the demographic model, compensate for the size of the age groups with the aim of maintaining the appropriate age structure using pre-calculated values for the maturation rates. These rates are used until enough time has passed so that the first generation of people that entered a certain age group has matured enough to exit that same group.

The initial values for immigration and emigration rates were calculated as averages of the values published by the Croatian Bureau of Statistics for the period from 2008 to 2012 [6], but the values relating to future immigration are only estimations designed to negate the effect of the proposed emigration rates on the total population. This decision was made to simplify the model because no current research is available to authors that would otherwise enable devising a more refined migration model.

\begin{tabular}{|c|c|c|c|}
\hline Period & Scenario 1 & Scenario 2 & Scenario 3 \\
\hline $2010-2014$ & 1.40 & 1.48 & 1.60 \\
\hline $2015-2019$ & 1.35 & 1.42 & 1.65 \\
\hline $2020-2024$ & 1.30 & 1.38 & 1.75 \\
\hline $2025-2029$ & 1.25 & 1.33 & 1.85 \\
\hline $2030-2034$ & 1.20 & 1.30 & 1.95 \\
\hline $2035-2039$ & 1.15 & 1.25 & 2.05 \\
\hline $2040-2044$ & 1.10 & 1.30 & 2.10 \\
\hline $2045-2049$ & 1.10 & 1.35 & 2.10 \\
\hline $2050-2054$ & 1.10 & 1.40 & 2.10 \\
\hline $2055-2059$ & 1.10 & 1.50 & 2.10 \\
\hline $2060-2064$ & 1.10 & 1.55 & 2.10 \\
\hline
\end{tabular}

Table 1: The predicted total fertility rates for the low-, medium-and high-fertility scenarios in the observed period. [6] 
A slight problem in the experiment design was the availability and existence of official data on and/or research into the military part of the model, especially for some lookups and variables. Where possible, official records and peer-reviewed papers were used as sources, but other values either came from less reliable sources (e.g. newspaper articles) or were conjectures based on circumstantial information or the author's estimates.

The "ACCEPTABILITY OF MILITARY SERVICE LOOKUP" is treated as an exogenous constant, with an estimated value of 0.45 , meaning that $45 \%$ of the population from the recruitment pool considers the possibility of military service as acceptable. The estimation is based on research done by Matika and Ogorec [16], indicating that $27.7 \%$ of respondents would like to find employment in the military, and $61.5 \%$ would seek employment in the military only as a last resort. The share of the second group in the total population from the recruitment pool is adjusted by the unemployment rate for that age group [3].

The "SHARE READY TO APPLY LOOKUP" is also treated as an exogenous constant, with a value of 0.01 . The estimation is based on unconfirmed reports that approx. 6,600 people applied for voluntary military training in the period between 2008 and 2011, equating to approx.. 2,200 people a year, or approx. $1 \%$ of the recruitment pool [13]. The value of "PLANNED TESTING LOOKUP" is estimated based on media reports regarding waiting periods and the assumed number of applicants [9].

The value of "PLANNED DIRECTION INTO SERVICE LOOKUP" is based on the number of applicants currently being admitted to voluntary military training on a yearly basis [18]. The value of the "GIVE UP" lookup is an estimation of the proportion of people that do not succeed in reaching the next phase of the recruitment process for whatever reason, and is more or less a free estimate due to the lack of any official data.

The values for the promotion, graduation, retirement and dismissal lookups is calculated based on the Plan for Admission into Active Military Service for the year 2014 [25] and the planned ratio of commissioned officers, NCO's and soldiers in active service according to the Strategic Defense Overview [18].

\subsection{Population dynamics simulation results}

The results of the population dynamics simulation show a significant decline in the population under all three scenarios due to low total fertility rates and low inflow of immigrants. However, there is a significant difference in the total population towards the end of the observed period due to a sizeable difference in the total fertility rate between the pessimistic Scenario 1 and the optimistic Scenario 3 . 
Total population

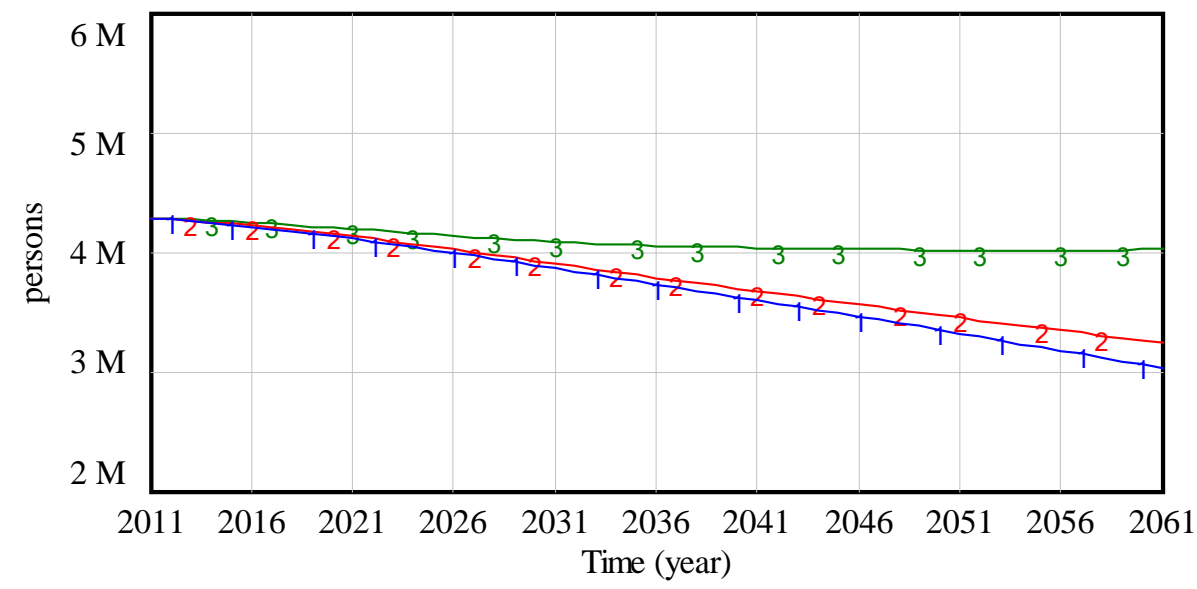

Total population : Scenario 1

Total population : Scenario 2

Total population : Scenario 3

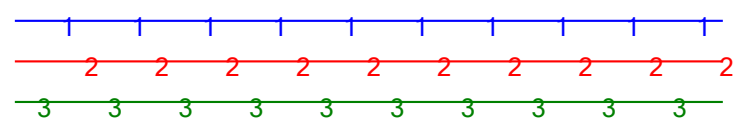

Figure 2: A graph illustrating changes in total population size based on proposed scenarios over the simulated period.

Given that members of the military are predominantly male, the population dynamics of different male age groups are shown to illustrate several important implications of the results provided by proposed demographic trends. The first important implication is that, although having an immediate effect on total population size, the impact of any change in the total fertility rate on the size of the workforce or the pool for military recruitment occurs after 18 years, as seen in Figure 4.

The second important implication is that the population of the "Male age 18 to 27 " cohort, which forms the base for military recruitment, experiences a significant decrease in all three scenarios. Although the population stabilizes at around 200,000 members in Scenario 3, its steady decline in Scenarios 1 and 2 lowers the expected population size to about 100,000 - a third of the population size at the beginning of the simulation. 


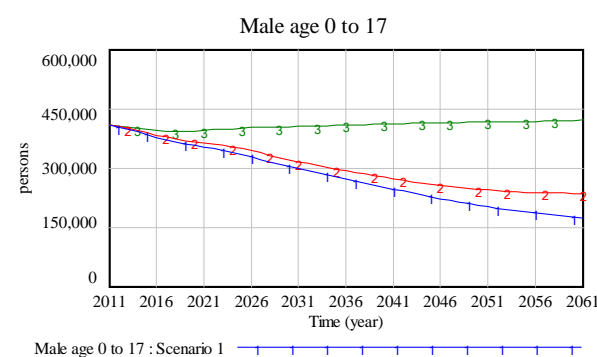

Male age 0 to 17 : Scenario 1
Male age 0 to $17:$ Scenario 2 Male age 0 to 17 : Scenario 2

Figure 3: Graphical representations of the simulation results for male populations aged 0 to 17 and 18 to 27 throughout the duration of the simulation in all three scenarios.

The third important implication concerns an increasingly unfavorable demographic structure. Due to the constant increase in life expectancy, and despite raising the retirement age limit, the results of the simulation suggest that the share of people in retirement age with respect to the total population will range from $25.21 \%$ to $33.44 \%$, depending on the scenario. Coupled with the projected decrease in the total population size, a significant decrease in the total workforce can be expected. Interestingly, although the high TFR in Scenario 3 has the least negative influence on the absolute workforce size, it decidedly has the most negative impact on the share of the workforce in the total population over the short- and medium-term. By the end of the simulation, the results of all scenarios converge toward a single point. The consequences of these trends will be discussed further in the discussion segment of the paper.

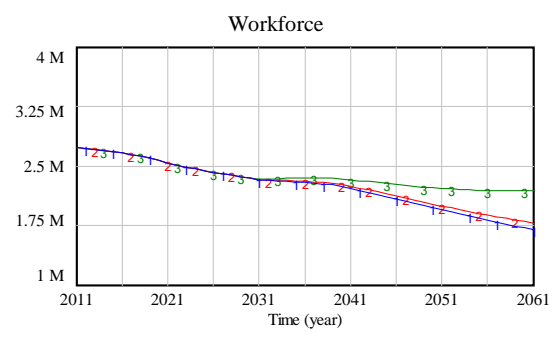

workforce : Scenario 1 workforce : Scenario 2
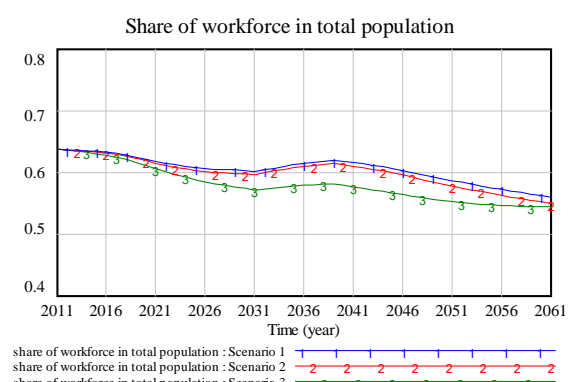

Figure 4: Graphical representations of the expected changes in the size of the workforce, as well as the share of workforce in the total population in all three scenarios.

\subsection{Results of the military dynamics simulation}

As expected, the reduction in the male and female populations between the ages of 18 and 27 caused a proportional decline in the recruitment pool in all three scenarios. In 2061, the model predicts its size to vary between 26,059 members 
in Scenario 1 to 108,011 in Scenario 3. Should "SHARE READY TO APPLY LOOKUP" have a constant value of one percent throughout the simulation, the model predicts that the number of active military personnel will begin declining rapidly in the year 2044 to a level well below the planned 15,000 troops [25].
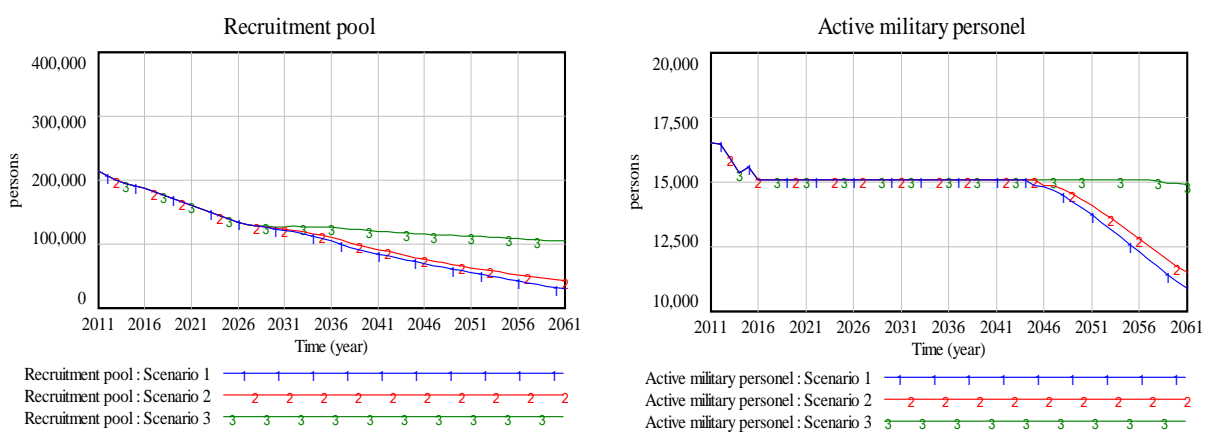

Figure 5: Graphical representations of expected changes in the sizes of the recruitment pool and active military personnel in all three scenarios.

The population drop also has an adverse effect on the total number of reserves that can be mustered in urgent situations. Total reserves experience a severe decline, dropping from 790,132 in 2011 to 323,112 in 2061 in Scenario 1, or to 516,420 in 2061 in Scenario 3. The graph of the "first contract" variable indicates that, after some volatility due to planned restructuring of the age and rank composition of the Croatian military, the decline in the number of active military personnel is closely correlated to the decrease in the number of new soldiers employed. The values of these important stocks and velocities are shown and compared in Table 2 below.
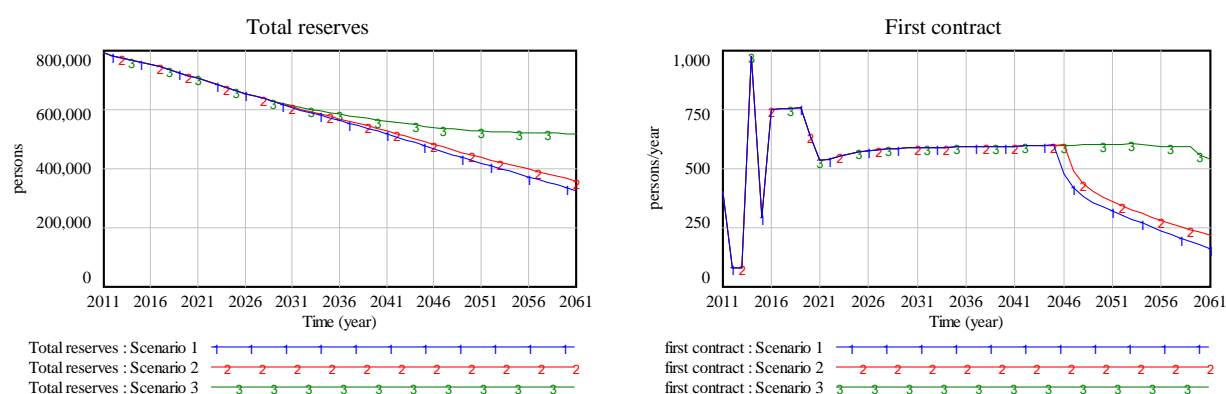

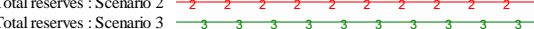

Figure 6: Graphical representations of expected changes in the number of the total reserves, and the number of people signing the first active military service contract in all three scenarios. 


\begin{tabular}{|l|c|c|c|c|c|c|}
\hline \multirow{2}{*}{ Variable name } & \multicolumn{2}{|c|}{ Scenario 1 } & \multicolumn{2}{c|}{ Scenario 2 } & \multicolumn{2}{c|}{ Scenario 3 } \\
\cline { 2 - 7 } & 2011 & 2061 & 2011 & 2061 & 2011 & 2061 \\
\hline Recruitment pool & 239600 & 26059 & 239600 & 40868 & 239600 & 108011 \\
\hline Went to VMT & 15000 & 707 & 15000 & 796 & 15000 & 1382 \\
\hline Soldiers & 5998 & 3215 & 5998 & 3746 & 5998 & 6735 \\
\hline $\begin{array}{l}\text { Non-commissioned } \\
\text { officers }\end{array}$ & 5778 & 4892 & 5778 & 4892 & 5778 & 4892 \\
\hline Commissioned officers & 3377 & 2547 & 3377 & 2547 & 3377 & 2547 \\
\hline $\begin{array}{l}\text { Active military } \\
\text { personnel }\end{array}$ & 16490 & 10878 & 16490 & 11486 & 16490 & 14869 \\
\hline Total reserves & 790132 & 323112 & 790132 & 356804 & 790132 & 516420 \\
\hline
\end{tabular}

Table 2: A comparison of values for relevant variables in all three scenarios in the years 2011 and 2061.

\section{Discussion}

The model structure and simulation results highlight several key issues significantly effecting long-term sustainability of the Croatian Armed Forces, starting with demographic trends already set in place.

Due to the current low fertility rate and the slightly negative migration balance, Croatia will probably experience a certain decrease in the working-age population. Retirement age reforms will mitigate some of these effects for a while, but the simulation results predict that, by the year 2061, the working-age population will fall by 540,269 people in best-case Scenario 3, and by 1,033,635 in worst-case Scenario 1.

Although high-fertility Scenario 3 would help stabilize the workforce size in the long-term, initial results would have an effect only after 18 years. By that time, the share of the workforce in the total population would decrease due to a combination of an increase in the number of children and an inc rease in the retirement-age population. The effects of the decrease are faster and more pronounced in Scenario 3, but, by the end of the simulation, the share of the workforce in the total population converges to around $55 \%$ in all three scenarios.

According to [21], an increase in the retirement-age population demands a large increase in public expenditure for pensions and health services. Coupled with a smaller tax base, some pressure will most likely be exerted to reduce military spending, or at least not to increase it any further. Given that wages are important in making a military career appealing [16] and the probable increase in competition on the private-sector job market [14], the military may experience a further reduction in size due to either a lack of interest or an increased share of trained soldiers leaving the military to join the civilian workforce. 
Some of the predicted negative effects can be mitigated by increasing the inflow of working-age immigrants into Croatia, which would increase the workforce size and reduce the competition posed by the private-sector job market to the military. However, while an increase in the number of immigrants can relieve the military of such pressure, it has no short-term effect on the recruitment pool size due to citizenship requirements for military employment. On the other hand, emigration has both an immediate and a long-term effect on the recruitment pool size, proportional to its volume and not to its net effect on the migratory balance, and as such represents a significant risk to adequate military recruitment.

\section{Conclusion}

The purpose of this paper is to outline the possibilities for using system dynamics in testing the sustainability of the Croatian Military Forces. It was approached from two perspectives: a demographic perspective and a military recruitment one. Appropriate models were developed in line with the basic principles of system dynamics, Croatian Law, as well as current demographic trends, and the simulation was built using publically available data to test the usefulness and realism of the models.

Following the simulation results that show an almost linear continuation of current trends in Scenarios 1 and 2, it is safe to assume that there is a higher probability that the demographic future of Croatia will follow along those lines. Although the recruitment pool will technically be sufficiently large to accommodate the needs of the Croatian military for recruits, success depends mostly on its ability to remain a competitive employer in spite of decreasing labor supply and mounting budgetary pressures due to growth in pension and public health expenditure.

Considering the long-term effects of demographic changes, in addition to the significant delay changes in fertility will have on the workforce, the results also highlight the necessity of creating long-term plans development plans. The introduction of scenario planning would assure a robustness of these long-term plans, whereas applying system dynamics in developing them would enable planners to optimize the favorable effects by making use of the relevant feedback loops.

The main advantages of the system dynamics approach are the inclusion of a broader perspective on sustainability, and the definition of variables exerting a potentially significant impact, that might not have been considered otherwise, all as a result of the actual modelling process. A significant potential exists for further improvement of the model with the inclusion of an economic sustainability module, which would enable both better use of feedback loops and 
provide the framework for explaining the processes behind most of the lookup variables in the model.

The main problem with the presented model is the relatively large number of lookups due to the lack of relevant research on which support models could be based to provide better results for creating a more useful model. Considering the potential benefits of such models, the authors recommend that more research should be conducted into this subject, especially in the field of external migrations and its causes. The authors also recommend increased use of system dynamics models as a decision support tool for policy making at all government levels.

\section{References}

[1] Anderson Jr., E. G. (2011). A dynamic model of counterinsurgency policy including the effects of intelligence, public security, popular support, and insurgent experience. System Dynamics Review, 27, 111-141. doi:10.1002/sdr.443.

[2] Artelli, M. J. and Deckro, R. F. (2008). Modelling the Lanchester Laws with system dynamics. The Journal of Defense Modeling and Simulation: Applications, Methodology, Technology, 5, 1, 1-20. doi:10.1177/154851290800500101.

[3] Banka (2011). Hrvatska druga po nezaposlenosti mladih u Europi (Croatia is the second in the youth unemployment in Europe). http://www.banka.hr/hrvatska/hrvatska-druga-po-nezaposlenosti-mladih-ueuropi [Accessed on 4 September 2014].

[4] Coyle, J. M., Exelby and D., Holt, J. (1999). System dynamics in defence analysis: Some case studies. Journal of the Operational Research Society, 50, 372-382. doi:10.2307/3010456.

[5] Coyle, R. G. and Gardiner, P. A. (1991). A systems dynamics model of submarine operations and maintenance schedules. Journal of the Operational Research Society, 42, 1, 453-462. doi:10.2307/2583453.

[6] Croatian Bureau of Statistics. (2009-2013). Migration of population of the Republic of Croatia. http://www.dzs.hr/default_e.htm [Accessed on 30 June 2014].

[7] Croatian Bureau of Statistics. (2012a). 2012 statistical yearbook of the Republic of Croatia. http:// http://www.dzs.hr/default_e.htm [Accessed on 1 September 2014].

[8] Croatian Bureau of Statistics. (2012b). Population by ethnicity, age and sex, 2011 census. http:// http://www.dzs.hr/default_e.htm [Accessed on 13 July 2013].

[9] Defender.hr (2012). Dragovoljni ročnici samo na liječnički pregled čekaju do dvije godine (Voluntary conscripts only for a physical are waiting up to two years). http://www. defender.hr/republika-hrvatska/obrambena-politika/dragovoljnirocnici-samo-na-lijecnicki-pregled-cekaju-do-dvije-godine.php [Accessed on 1 September 2014].

[10] Fan, C.Y., Fan, P.S. and Chang, P.C. (2010). A system dynamics modeling approach for a military weapon maintenance supply system. International Journal of Production economics, 128, 457-469. doi:10.1016/j.ijpe.2010.07.015. 
[11] Garza, A., Martin, J. D., Finke, D. A. and Kumara, S. (2014). System dynamics based manpower modeling. In: Guan, Y. and Liao, H. (Eds.). Proceeding of the 2014 Industrial and Systems Engineering Research Conference (pp. 3683 - 3692). Norcross, GA: Institute of Industrial Engineers.

[12] Gelo, J., Akrap, A. and Čipin, I. (2005.), Temeljne značajke demografskog razvoja Hrvatske: Bilanca 20. stoljeća (The basic features of demographic development of Croatia: Balance sheet of the 20th century). Zagreb: Ministarstvo obitelji, branitelja i medugeneracijske solidarnosti (Ministry of the family, veterans' affairs and intergenerational solidarity).

[13] Glas Slavonije (2013). Dragovoljno služenje vojnog roka ne znači i dobivanje posla u GV-u (Voluntary military service does not mean getting a job in the GV.). http://www.glas-slavonije.hr/207461/1/Dragovoljno-sluzenje-vojnog-roka-neznaci-i-dobivanje-posla-u-HV-u [Accessed on 1 September 2014].

[14] Karnjuš, I. (2008). Financiranje obrane (Defense Funding). Zagreb: Golden marketing - Tehnička knjiga (Zagreb: Golden marketing - Tehnical book), Institut za razvoj i istraživanje obrambenih sustava (Institute for Research and Development of Defense Systems).

[15] Lyneis, J. M., Cooper, K. G. and Els, S. A. (2001). Strategic management of complex projects: A case study using system dynamics. System Dynamics Review, 17, 237-260. doi:10.1002/sdr.213.

[16] Matika, D. and Ogorec, M. (2010). Gospodarska kriza i poželjnost odabira vojnog poziva (The economic crisis and the desirability of choosing the military call). Društvena istraživanja (Social Research), 21, 1, 121-136.

[17] Ministarstvo unutarnjih poslova (2014). Zakon o hrvatskom državljanstvu (The Croatian Citizenship Act). http://www.mup.hr/main.aspx?id=96\#1 [Accessed on 04 September 2014].

[18] Narodne Novine. (2013a). Strateški pregled obrane (Strategic defence review). http://narodne-novine.nn.hr/clanci/sluzbeni/2013_08_101_2285.html[Accessed on 1 September 2014].

[19] Narodne Novine. (2013b). Zakon o obrani (The Law on Defence). http://narodnenovine.nn.hr/clanci/sluzbeni/2013_06_73_1452.html [Accessed on 1 September 2014].

[20] Narodne Novine. (2013c). Zakon o službi u Oružanim snagama Republike Hrvatske (The Law on the Service in the Armed Forces of the Republic of Croatia). http://narodne-novine.nn.hr/clanci/sluzbeni/2013_06_73_1453.html [Accessed on 01 September 2014]

[21] Nejašmić, I. (2014). Kamo ide Hrvatska? Buduće demografske promjene i neke njihove posljedice (Where goes Croatia? Future demographic changes and some of their consequences). In: Akrap, A., Čipin, I. and Strmota, M. (Eds.). Demografija u Hrvatskoj (Demography in Croatia) (pp. 111 - 122). Zagreb: Ekonomski fakultet Zagreb (Zagreb: Faculty of economics).

[22] Pejić-Bach, M. and Čerić, V. (2007). Developing system dynamics models with "step-by-step" approach. Journal of Information and Organizational Sciences, 31, 1, 171-185.

[23] Stiglitz, J. E. (2000). Economics of the Public Sector. Third Edition. New York City: W. W. Norton \& Company. 
[24] Stockholm International Peace Research Institute (2013). SIPRI Fact Sheet Trends in World Military Expenditure, 2012.

http://books.sipri.org/files/FS/SIPRIFS1304.pdf [Accessed on 1 September 2014].

[25] Vlada Republike Hrvatske. (Croatian Government) (2014). Plan prijma osoblja u djelatnu vojnu službu za 2014. godinu (Plan of staff reception in the active military service in 2014).

https://vlada.gov.hr/UserDocsImages//Sjednice/Arhiva//138.\%20-\%2025.pdf [Accessed on 1 September 2014].

[26] Vrankić, I. (2001.) Modeliranje i simulacija upravljanja sustavom opće vojne obveze metodom sistemske dinamike (Modeling and simulation of compulsory military duty system management by method of system dynamics.). Magistarski rad (Master's thesis). Zagreb: Ekonomski fakultet (Zagreb: Faculty of economics).

[27] Wang, J. (2007). A system dynamics simulation model for a four-rank military workforce. DSTO Defence Science and Technoglogy Organization, Edinburgh, Australia.

[28] Wils, A., Kamiya, M. and Choncri N, (1998). Threats to sustainability: Simulating conflict within and between nations. System Dynamics Review, 14, 129-162. 